\title{
ACUTE EFFECTS OF DIFFERENT STRETCHING DURATIONS ON VERTICAL JUMP PERFORMANCE IN RHYTHMIC GYMNASTS
}

\author{
Nuriye Özengin ${ }^{1}$, Necmiye Ün Yıldırım ${ }^{1}$, Gül Baltacı ${ }^{2}$, Nerijus Masiulis ${ }^{3}$ \\ Abant Izzet Baysal University', Bolu, Turkey \\ Hacettepe University', Ankara, Turkey \\ Lithuanian Academy of Physical Education, Kaunas, Lithuania
}

\begin{abstract}
Research background. Stretching is believed to enhance performance, reduce injury, and be an effective means of developing flexibility and alleviating muscular soreness (Shellock, Prentice, 1985; Brandy et al., 1997). A review of the current literature shows that the results of many studies conflict with others; some report that static stretching diminishes vertical jum (VJ) performance (Cornwell et al., 2001; McNeal, Sands, 2003; Wallmann et al., 2005), whereas others report that static stretching has no effect at all on VJ (Church et al., 2001; Power et al., 2004; Unick et al., 2005).

Research aim, was to examine the effects of different durations of stretching on performance and to find the stretching durations that affect the performance negatively or positively.

Research methods. The subjects of the study were 27 rhythmic gymnasts with the mean age of $10.00 \pm 1.2$ years. The subjects as a whole group participated in two different stretching programs on nonconsecutive days to eliminate the effect of individual differences on the performance. On the first day, athletes were asked to warm up by 5 minute jogging after the pretest was administered. The posttest measured the vertical jump performance after athletes stayed inactive for 20 minutes. They rested for a day and on the third day, their performance was measured again. After the 5 minute warm-up period, 10 repetitions of 15 seconds static stretching exercises for hip flexor, hamstring and gastrocnemius muscle groups were followed by the posttest. Moreover, on the fifth day 30 -second exercises were repeated five times on the same type of muscles. The participants in this investigation were tested in individual vertical jump performances following warm-up only, warm-up plus 15 seconds static stretching, and warm-up plus 30 seconds.

Research results. Results of a one-way repeated-measures ANOVA indicated a nonsignificant difference for vertical jump performance $(\mathrm{F}=2.052 ; \mathrm{p}>0.05)$.

Discussion and conclusions. Stretching exercises are referred in rhythmic gymnastics more intensively than other sports. Relevant literature displays fewer stretching repetitions and durations. These durations and repetitions may not be realistic and practical for rhythmic gymnasts. Therefore, the durations and repetitions utilized in this study are considered more appropriate for rhythmic gymnastics trainings.

Rhythmic gymnasts may make use of duration and repetitions determined in this study that will not affect their performance.
\end{abstract}

Keywords: anaerobic power, gymnastics, exercise.

\section{INTRODUCTION}

$\mathrm{S}$ tretching is commonly used by athletes in different sports. Stretching can alter the range of motion about a joint and improve flexibility (Stone et al., 2006). However, stretching as part of a warm-up may reduce performance. Most available data indicates that acute performance reduction can occur and it may be related to decreased tissue stiffness or alterations in nervous system components of the stretch-shortening cycle, such as the myototic reflex (Stone et al., 2006). These alterations in turn can result in a decreased maximum strength and explosiveness and inferior performances (Stone et al., 2006). Several studies were carried out on vertical jump performance to see the effect of stretching. A. G. Nelson et al. (1996) investigated 
vertical jump performance after passive stretching in untrained men. They reported a decrease in vertical jump height after both countermovement and squat jumps after stretching the hip extensors and knee flexors (Nelson et al., 1996). J. B. Church et al. (2001) identified a decrease in vertical jump performance after an intervention of proprioceptive neuromuscular facilitation (PNF) of the hamstrings and quadriceps muscles on 40 female participants (Church et al., 2001). A. Cornwell et al. (1999) investigated the effects of passive stretching of triceps surae on static jump and countermovement jump performance. They concluded that there was a significant decrease in countermovement jump after stretching of the triceps surae complex (Cornwell et al., 1999).

Although available research findings displayed decrease in the performance due to acute stretching, stretching seems to be very important in high stretch-shortening cycles (SSCs) sports. It is generally accepted that increasing the flexibility of a muscle-tendon unit promotes better performances and decreases the number of injuries (Witvrouw et al., 2004). Muscle-tendon units can store mechanical work as elastic energy during eccentric contractions. The storage and subsequent release of elastic energy during SSCs have generally been considered as an 'energysaving' mechanism (van Ingen Schenau et al., 1997). Therefore, it seems that different types of sports need different levels of musculo-tendinous stifness. Sports involving bouncing and jumping activities with a high intensity of SSCs (e.g. soccer and football) require a muscle-tendon unit that is stiff enough to store and release the high amount of elastic energy that benefits performance in such sports (Witvrouw et al., 2004).

S. Magnusson et al. (2000) showed that 3 sets of 45 seconds of stretching had no acute effect on the viscoelastic properties of the hamstring muscle (Magnusson et al., 2000). J. Unick et al. (2005) suggested that the quantity of stretching used in their study ( 3 sets of 15 seconds) may not have been enough to alter the viscoelastic properties of the muscles (Unick et al., 2005). A. di Cagno et al. (2010) concluded that more than 30 seconds for each stretch exercise duration has a detrimental effect on performances. K. Power et al. (2004) found plantar flexors, hamstrings, and quadriceps activation impairment because of SS held for 4.5 minutes (Power et al., 2004).

Gymnasts represent a group of athletes for whom stretching is a major component of training (Sands,
1988; Sands, McNeal, 2000). Gymnasts often perform a variety of active and passive stretches as part of their warm-up, as well as during their sport specific training activities (McNeal, Sands, 2003). The current literature lacks such research on female rhymtic gymnasts. Hence, this study aims at filling this gap by examining the acute effects of streching exercises on performances of females between the age of 8 and 12. The purpose of this study was to examine the acute effects of different stretching durations on vertical jump performance in female rhythmic gymnasts.

\section{RESEARCH METHODS}

Subjects. Thirty-five female rhythmic gymnasts initially volunteered to take part in this study. Five rhythmic gymnasts did not complete all study procedures, and 3 rhythmic gymnasts with pre-existing lower extremity injuries were not permitted to participate. No subject withdrew due to injury or any other adverse experiences. The final sample consisted of 27 rhythmic gymnasts. The mean \pm SD for age, height, weight and body mass index of subjects who completed all study procedures was $10.00 \pm 1.20$ years, $1.37 \pm 0.08 \mathrm{~m}$, $31.66 \pm 6.33 \mathrm{~kg}$ and $16.63 \pm 1.43 \mathrm{~kg} / \mathrm{m}^{2}$ respectively. Families and trainers of the subjects were verbally informed of the procedures, and read and signed a consent form before the study. The study was approved by the Abant Izzet Baysal University Ethics Committee.

Procedures. Stretching program was practiced on nonconsecutive days. Two different stretching programs with two different stretching durations were applied to all athletes. Performance of athletes was evaluated both before and as soon as possible after the stretching. The subjects as a whole group participated in two different stretching programs on nonconsecutive days to eliminate the effect of individual differences on the performance. On the first day, athletes were asked to warm up by 5 minute jogging after the pretest was administered. The posttest measured the vertical jump performance after athletes stayed inactive for 20 minutes. They rested for a day and on the third day, their performance was measured again. After the 5 minute warm-up period, 10 repetitions of 15 seconds static stretching exercises on hip flexor, hamstring and gastrocnemius for each muscle groups were followed by the posttest. Moreover, on the fifth day 30 -second exercises were repeated five times on the same type of muscles. Stretching 
Table 1. Stretching protocols applied to athletes in this study

\begin{tabular}{|c|c|c|c|c|}
\hline $1^{\text {st }}$ day & $2^{\text {nd }}$ day & $3^{\text {rd day }}$ & $4^{\text {th }}$ day & $5^{\text {th }}$ day \\
\hline $\begin{array}{c}\text { Measurement of performance } \\
\text { (pre-test) } \\
\downarrow \\
\text { Warm-up } \\
\downarrow \\
20 \text { min rest } \\
\downarrow \\
\text { Measurement of performance } \\
\text { (post-test) }\end{array}$ & Rest & $\begin{array}{c}\text { Measurement of performance } \\
\text { (pre-test) } \\
\downarrow \\
\text { Warm-up } \\
\downarrow \\
15 \mathrm{sec}-10 \text { repetitions } \\
\text { static stretching exercises } \\
\text { to hip flexor, hamstring and } \\
\text { gastrocnemius } \\
\downarrow \\
\text { Measurement of performance } \\
\text { (post-test) }\end{array}$ & Rest & $\begin{array}{c}\text { Measurement of performance } \\
\text { (pre-test) } \\
\downarrow \\
\text { Warm-up } \\
\downarrow \\
30 \mathrm{sec}-5 \text { repetitions static } \\
\text { stretching exercises to } \\
\text { hip flexor, hamstring and } \\
\text { gastrocnemius } \\
\downarrow \\
\text { Measurement of performance } \\
\text { (post-test) }\end{array}$ \\
\hline
\end{tabular}

protocols that were applied are summarized in Table 1.

Stretching Protocol. The two types of stretching durations and repetitions used in this study were 10 repetitions of 15 seconds and 5 repetitions of 30 seconds. All stretching were held to the onset tension, which was explained to the subjects as stretchings the muscle to the greatest voluntary length beyond which the subjects would feel pain might occur. The stretching protocol consisted of the following 3 stretches targeting muscles: hip flexors, hamstring, and gastrocnemius.

To stretch the hip flexors forward lunge was utilized. First, subjects stepped forward with the non-stretched leg and flexed this knee until it was directly over the foot, keeping it flat on the floor and the back leg straight. Afterwards, the back foot pointed toward the front foot not necessarily placed the back heel on the floor. Subjects then kept their body upright and rested their hands on the hips or in front of the leg. Finally, they stretched towards the floor throughout the protocol duration. One-legged standing stretch was used to stretch the hamstrings. In the standing position, subjects placed their stretched leg on a padded bench. The non-stretched leg pointed ahead with knee either fully extended or just slightly flexed. In this position, each subject leaned forward from the hips towards the elevated foot while ensuring to maintain a straight back. During the stretching, the knee of the stretched leg remained in a neutral position. Subjects leaned forward until a mild discomfort was felt in the hamstrings. Upon reaching this position, each subject was asked to hold this stretch for the duration of the protocol.

In order to stretch the gastrocnemius, the standing straight knee stretch was used. The subjects faced a wall and leaned against it with outstretched arms while bending the front leg at approximately $90^{\circ}$ and keeping the other leg fully extended behind the body. The heel of the back leg remained in contact with the floor at all times while the subjects dorsiflexed the ankle of extended back leg.

Jump Performance Test. The vertical jump test was originally used by C. Bosco et al. (1983) to assess the lower-limb explosive performance capacity. The test was performed on a contact platform (Newtest, Oulu, Finland), which gives the time the subject is on air in milliseconds. Prior to the test, athletes were asked to wear shorts and cotton shirt, and to take off their trainers. The subjects started with the foot of the designated testing leg on the contact mat and their hands on their hips, they were then instructed to squatted (approximately $120^{\circ}$ knee angle) as quickly as possible and then jumped as high as possible in the ensuring concentric phase (Maulder, Cronin, 2005). Subjects performed three trials in the protocol and the best one was used in the analysis. Power output was calculated by the following equation:

Power $(\mathrm{kg}-\mathrm{m} / \mathrm{sn})$ : weight $(\mathrm{kg}) \mathrm{x}$ distance $(\mathrm{m}) /$ time (s).

Statistical Analyses. To determine the effect that the stretching duration had on the vertical jump test, a one-way repeated-measures analysis of variance (ANOVA) was used. This method provides a measure of the actual mean differences between stretching conditions. Any significant differences found by the one-way repeated-measures ANOVA were followed by paired t-test analysis. Statistical significance in this investigation was set at $\mathrm{p}<0.05$.

\section{RESEARCH RESULTS}

The participants in this investigation were tested in individual vertical jump performances following warm-up only, warm-up plus 15 seconds static stretching, and warm-up plus 30 seconds. Results 


\begin{tabular}{|c|c|c|}
\hline $\begin{array}{c}\text { Vertical jump } \\
(\mathbf{k g}-\mathbf{m} / \mathbf{s})\end{array}$ & $\begin{array}{c}\text { Pre-test } \\
\mathbf{( n = 2 7 )} \\
\mathbf{X} \pm \mathbf{S D}\end{array}$ & $\begin{array}{c}\text { Post-test } \\
\mathbf{( n = 2 7 )} \\
\mathbf{X} \pm \mathbf{S D}\end{array}$ \\
\hline $1^{\text {st }}$ day & $16.17 \pm 3.80$ & $16.43 \pm 4.24$ \\
\hline $3^{\text {rd }}$ day & $16.43 \pm 4.24$ & $16.12 \pm 3.97$ \\
\hline $5^{\text {th }}$ day & $16.77 \pm 4.04$ & $16.73 \pm 3.97$ \\
\hline
\end{tabular}

Table 2. The vertical jump mean (SD) results

of a one-way repeated-measures ANOVA indicated a nonsignificant difference for vertical jump performance $(F=2.052 ; p>0.05)$ (see Table 2$)$.

\section{DISCUSSION}

The purpose of this study was to determine the acute effects of static stretching on vertical jump performance and to investigate different durations of acute stretching on performance in rhythmic gymnasts. In this study, no significant decrease in vertical jump performance was found in the 15 and 30 second static stretching duration. These results differed from several previous studies that found a decrease in vertical jump as a result of stretching (Cornwell et al., 2001; Young, Elliot, 2001; Cornwell et al., 2002; McNeal, Sands, 2003; Faigenbaum et al., 2005; Wallmann et al., 2005; Glenn et al., 2006; Behm, Kibele, 2007; Bradley et al., 2007; Vetter et al., 2007; Robbins, Scheuermann, 2008).

A few reasons can be theorized as to why vertical jump performance stayed unaltered. The present study consisted of female athletes. K. Kubo et al. (2003) investigated sex differences in the viscoelastic properties of tendon structures and found that women had decreased tendon stiffness in their medial gastrocnemius muscle as compared with the males within their study. An increase in muscle compliance has been forwarded as a hypothesis to explain the loss of muscular performance after static stretching. It is possible that women are less affected by static stretching because of their already reduced stiffness of the musculotendinous units of the targeted muscles (Kubo et al., 2003).

Time spent between static stretching exercise and vertical jump test is vital. Because the recovery of motor neuron excitability is other explanation as to why vertical jump performance was unaltered as a result of static stretching. Many previous researchers have used Hoffman reflex (H-reflex) measures as an indicator of changes in motorneuron excitability (Guissard et al., 1988; Avela et al., 1999; Earles et al., 2002). In a study by J. Avela et al. (1999), effect of prolonged and repeated stretching on sensitivity was examined. The results of their study found a depression of the H-reflex after stretching but showed that the strength of this reflex was almost completely recovered 4 minutes after stretching (Avela et al., 1999). W. Guissard et al. (1988) also studied the H-reflex and found it to quickly recover immediately following static stretching. Therefore, the "resting period" between the stretching phase and jumping phase could have allowed a return in neuromotor excitability, causing any alteration that had occurred to return the prestretching or near prestretching status (Unick et al., 2005). In this study, vertical jump performance measurement was carried out longer than 4 minutes after static stretching to allow time for subjects to get prepared.

Several studies found that static stretching did not result in a performance decrease (Power, 2004; Guissard, Reiles, 2005; Cramer, 2007; Ufuk, David, 2007; Beedle, 2008; Cé et al., 2008; Samuel, 2008). Additionally, W. Young and S. Elliot (2001) found a nonsignificant decrease in the squat jump with 45 seconds of stretching per muscle group (3 sets of 15 seconds). J. B. Church et al. (2001) used women in their study comparing proprioceptive neuromuscular facilitation and static stretching and found that static stretching did not affect vertical jump. L. Burkett et al. (2001) studied the effectiveness of two specific and nonspecific warm-ups on vertical jump performance in women athletes and observed that a static stretching routine did not cause any significant changes to vertical jump when compared with the control condition. J. Unick et al. (2005) investigated the acute effects of static and ballistic stretching on vertical jump and concluded that neither stretching routine affected performance.

It is known that stretching exercises to enhance the flexibility are included both in the training programs and warm-up activities of many athletes (Gleim, McHugh, 1997). Sports involving "explosive" type skills (e. g. gymnastics), with many and maximal SSC movement require a muscle-tendon unit which is stiff enough to store and release the high amount of elastic energy. 
Recently, it has been shown that stretching is able to increase the compliance of human tendons and, as a result increase the capacity of the tendon to absorb energy. When an individual's muscletendon unit is less flexible in these types of sports activities, there exists a predisposing factor for exercise-related injuries since the tendon is unable to absorb enough energy, which may lead to tendon and/or muscle damage (Witvrouw et al., 2004). Moreover, whether stretching exercises before the trainings negatively affect the performance or not are still confusing. This study examining the effect of 15 and 30 seconds static stretching on the performance of gymnasts show no change in the vertical jump test values after the 15 and 30 -second stretching.

\section{CONCLUSIONS AND PERSPECTIVES}

Stretching exercises are referred in rhythmic gymnastics more intensively than other sports. Relevant literature displays fewer stretching repetitions and durations. These durations and repetitions may not be realistic and practical for rhythmic gymnasts. Therefore, the durations and repetitions utilized in this study are considered more appropriate for rhythmic gymnastics training. We concluded that rhythmic gymnasts may make use of duration and repetitions determined in this study that will not affect their performance.

\section{REFERENCES}

Avela, J., Kryolainen, H., Komi, P., Rama, D. (1999). Reduced reflex sensitivity persists several days after long-lasting stretch-shortening cycle Exercise. Journal of Applied Physiology, 86, 1292-1300.

Bandy, W. D., Irion, J. M., Briggler, M. (1997). The effect of time and frequency of static stretching on flexibility of the hamstring muscles. Physical Therapy, 77, 1090-1096.

Beedle, B., Rytter, S. J., Healy, R. C., Ward, T. R. (2008). Pretesting static and dynamic stretching does not affect maximal strength. Journal of Strength and Conditioning Research, 22 (6), 1838-1843.

Behm, D. G., Kibele, A. (2007). Effects of differing intensities of static stretching on jump performance. European Journal of Applied Physiology, 101, 587-594.

Bosco, C., Luhtanen, P., Komi, P. V. (1983). A simple method for measurement of mechanical power in jumping. European Journal of Applied Physiology, 50, 273-282.

Bradley, P. S., Olsen, P. D., Portas, M. D. (2007). The effect of static, ballistic, and proprioceptive neuromuscular facilitation stretching on vertical jump performance. Journal of Strength and Conditioning Research, 21 (1), 223-226.

Burkett, L., Ziuraitis, J., Philipis, W. (2001). The effect of four different warm-ups on the maximum vertical jump test scores for female college athletes. Women in Sport and Physical Acitivity Journal, 10, 83-94.

di Cagno, A., Baldari, C., Battaglia, C. et al. (2010). Preexercise static stretching effect on leaping performance in elite rhythmic gymnasts. Journal of Strength and Conditioning Research, 24 (8), 1995-2000.

Cé, E., Margonato, V., Casasco, M., Veicsteinas, A. (2008). Effects of stretching on maximal anaerobic power: The roles of active and passive warm-ups. Journal of Strength and Conditioning Research, 22 (3), 794-800.

Church, J. B., Wiggins, M. S., Moode, M. F., Crist, R. (2001). Effect of warm-up and flexibility treatments on vertical jump performance. Journal of Strength and Conditioning Research, 15, 332-336.

Cornwell, A., Nelson, A. G., Heise, G. D., Sidaway, B. (2001). Acute effects of passive muscle stretching on vertical jump performance. Journal of Human Movement Studies, 40, 307-324.

Cornwell, A., Nelson, A. G., Sidaway, B. (1999). Acute effects of passive stretcing on the neuromechanical behavior of the triceps surae muscle complex. Medicine and Science in Sports and Exercise, 31, S 221.

Cornwell, A., Nelson, A. G., Sidaway, B. (2002). Acute effects of stretching on the neuromechanical properties of the triceps surae muscle complex. European Journal of Applied Physiology, 86, 428-434.

Cramer, J. T., Housh, T. J., Johnson, G. O. et al. (2007). An acute bout of static stretching does not affect maximal eccentric isokinetic peak torque, the joint angle at peak torque, mean power, electromyography, or mechanomyography. Journal of Orthopaedic Sports Physical Therapy, 37, 130-139.

Earles, D., Dierking, C., Robertson, C., Koceja, D. (2002). Pre- and post- synaptic control of motoneuron 
excitability in athletes. Medicine and Sscience in Sports and Exercise, 34, 1766-1772.

Faigenbaum, A. D., Bellucci, M., Bernieri, A. et al. (2005). Acute effects of different warm-up protocols on fitness performance in children. Journal of Strength and Conditioning Research, 19 (2), 376-381.

Gleim, G. W., McHugh, M. P. (1997). Flexibility and its effects on sports injury and performance. Sports Medicine, 24, 289-299.

Glenn, W., Lucinda, W., John, G., Carl, F. (2006). Effects of static stretching, dynamic stretching, and warm-up on active hip range of motion and vertical jump. Medicine and Science in Sports and Exercise, 38 (5), S 280-281.

Guissard, N., Duchateau, J., Hainaut, K. (1988). Muscle stretching and motoneuron excitability. European Journal of Applied Physiology and Occupational Physiology, 58, 47-52.

Guissard, N., Reiles, F. (2005). Effects of stretching and contract relax methods on the force production and jump performance. Computer Methods in Biomechanics and Biomedical Engineering, Supplement 1, 127-128.

van Ingen Schenau, G. J., Bobbert, M. F., de Haan, A. (1997). Does elastic energy enhance work and efficiency in the stretch-shortening cycle? Journal of Applied Biomechanics, 13, 389-415.

Kubo, K., Kanehisa, H., Fukunaga, T. (2003). Gender differences in the viscoelastic properties of tendon structures. European Journal of Applied Physiology, 88, $520-526$.

Magnusson, S., Aagaard, P., Nielson J. (2000). Passive energy return after repeated stretches of the hamstring muscle-tendon unit. Medicine and Science in Sports and Exercise, 33, 1160-1164.

Maulder, P., Cronin, J. (2005). Horizontal and vertical jump assessment: reliability, symmetry, discriminative and predictive ability. Physical Therapy in Sport, 6, 74-82.

McNeal, J. R., Sands W. A. (2003). Acute static stretching reduces lower extremity power in trained children. Pediatric Exercise Science, 15, 139-145.

Nelson, A. G., Cornwell, A., Heise, G. D. (1996). Acute stretching exercises and vertical jump stored elastic energy. Medicine and Science in Sports and Exercise, 28, S 156.

Power, K., Behm, D., Cahill, F. et al. (2004). An acute bout of static stretching: Effects on force and jumping performance. Medicine and Science in Sports and Exercise, 36 (8), 1389-1396.

Robbins, J. W., Scheuermann, B. W. (2008). Varying amounts of acute static stretching and its effect on vertical jump performance. Journal of Strength and Conditioning Research, 22 (3), 781-786.

Samuel, M. N., Holcomb, W. R., Guadagnoli, M. A. et al. (2008). Acute effects of static and ballistic stretching on measures of stregth and power. Journal of Strength and Conditioning Research, 22 (5), 1422-1428.

Sands, W. A. (1988). Gymnastics Federation physical abilities testing for women. Technique, 8 (3-4), 27-32.

Sands, W. A., McNeal, J. R. (2000). Enhancing flexibility in gymnastics. Technique, 20, 6-9.

Shellock, F. G., Prentice, W. E. (1985). Warming up and stretching for improved physical performance and prevention of sports related injuries. Sports Medicine, 2, 267-278.

Stone, M., Ramsey, M. W., Kinser, A. M. et al. (2006). Stretching: Acute and chronic? The potential consequences. Strength and Conditioning Journal, 28 (6), 66-74.

Ufuk, A., David. K. (2007). The effects of acute static stretching on reaction time and force. The Journal of Sports Medicine and Physical Fitness, 47 (2), 147-150.

Unick, J., Keiffer, S. H., Cheesman, W., Feeney, A. (2005). The acute effects of static and ballistic stretching on vertical jump performance in trained women. Journal of Strength and Conditioning Research, 19 (1), 206-212.

Vetter, R. E. (2007). Effects of six warm-up protocols on sprint and jump performance. Journal of Strength and Conditioning Research, 21 (3), 819-823.

Wallmann, H. W., Mercer, J. A., McWhorter, J. W. (2005). Surface electromyographic assessment of the effect of static stretching of the gastrocnemius on vertical jump performance. Journal of Strength and Conditioning Research, 19 (3), 684-688.

Witvrouw, E., Mahieu, N., Danneels, L., McNair, P. (2004). Stretching and injury prevention an obscure relationship. Sports medicine, 34(7), 443-449.

Young, W., Elliot, S. (2001). Acute effects of static stretching, proprioceptive neuromuscular facilitation stretching, and maximum voluntary contractions on explosive force production and jumping performance. Research Quarterly for Exercise and Sport, 72, 273-282. 


\title{
GREITOJI ADAPTACIJA PRIE MENINĖS GIMNASTIKOS VERTIKALIŲ ŠUOLIŲ ATLIEKANT SKIRTINGOS TRUKMĖS TEMPIMO PRATIMUS
}

\author{
Nuriye Özengin¹, Necmiye Ün Yıldırım¹, Gül Baltacı², Nerijus Masiulis ${ }^{3}$ \\ Abant Izzet Baysal universitetas ${ }^{1}$, Bolu, Turkija \\ Hacettepe universitetas ${ }^{2}$, Ankara, Turkija \\ Lietuvos kūno kultūros akademija ${ }^{3}$, Kaunas, Lietuva
}

\section{SANTRAUKA}

Tyrimo pagrindimas ir hipoteze. Manoma, kad tempimo pratimai pagerina raumenų darbą, mažina traumų tikimybę ir yra veiksminga lankstumo lavinimo priemonè, padedanti mažinti raumenų skausmą (Shellock, Prentice, 1985; Brandy et al., 1997). Daugelio tyrimų rezultatai prieštarauja vieni kitiems - kai kuriuose teigiama, kad statinis tempimas sumažina raumenų veiklą vertikalių šuolių metu (Cornwell et al., 2001; McNeal, Sands, 2003; Wallmann et al., 2005), kiti teigia, kad statinis tempimas neturi jokio poveikio vertikaliems šuoliams (Church et al., 2001; Power et al., 2004; Unick et al., 2005).

Tikslas: ištirti, kaip įvairios trukmės tempimo pratimai veikia raumenų darbą ir nustatyti optimalią tempimo pratimų trukmę.

Metodai. Buvo tiriami 27 meninès gimnastikos sportininkai, kurių amžiaus vidurkis $-10,00 \pm 1,2$ metų. Ne tomis pačiomis dienomis visai grupei buvo taikomos dvi skirtingos raumenų tempimo pratimų programos. Pirmą dieną sportininkų buvo prašoma atlikti 5 minučių trukmės pramankštą bėgant. Po 20 minučių pertraukos išmatuotas vertikalaus šuolio aukštis, tada vieną dieną ilsimasi, o trečią - vèl vertinami šuoliai. Po pramankštos buvo taikomi statiniai dubens, šlaunies ir blauzdos raumenų tempimo pratimai atliekant 10 kartojimų po 15 sekundžių. Be to, penktą dieną toms pačioms raumenų grupėms buvo taikyti 30 sekundžių trukmės tempimo pratimai, kartojami po penkis kartus. Testuotas tik individualus tiriamujų vertikalių šuolių atlikimas po pramankštos pratimų, po pramankštos ir po 15 sekundžių statinio tempimo, po pramankštos ir 30 sekundžių tempimo.

Rezultatai. Pakartotinių matavimų dispersinès analizès rezultatai parodė neesminius vertikalių šuolių atlikimo skirtumus $(\mathrm{F}=2,052 ; \mathrm{p}>0,05)$.

Aptarimas ir išvados. Šis tyrimas neatskleide pokyčių vertinant vertikalų šuoli. Meninès gimnastikos pratybose tempimo pratimai yra daugiau taikomi nei kitų sporto šakų. Literatūros šaltiniuose pateikiamos skirtingos tempimo pratimų kartojimo ir trukmės rekomendacijos. Šiuo tyrimu nurodoma pratimų atlikimo trukmė ir kartojimų skaičius labiau tinka per meninės gimnastikos pratybas, bet sportininkams didesnio poveikio neturi.

Raktažodžiai: anaerobinis galingumas, gimnastika, pratimas.

Gauta 2011 m. liepos 30 d.

Received on July 30, 2011

Corresponding author Nuriye Özengin

Abant İzzet Baysal University, Physical Therapy

and Rehabilitation School

Bolu, Turkey

Tel +9003742534661

E-mail ozenginnuriye@yahoo.com 